6. Ou X. H. Effects of obesity and diabetes on the epigenetic modification of mammalian gametes / X. H. Ou , C. C. Zhu, S. C. Sun // J Cell Physiol. - 2018. doi: 10.1002/jcp.27847

7. The effect of weight loss on lameness in obese dogs with osteoarthritis / W. G. Marshall, H. AW. Hazelwinkel, D. Mullen et al. // Vet Res Comm. - 2010. - 34. P. 241-253.

8. Histomorphometric changes in the perirenal adipocytes of adrenalectomized rats treated with dexamethasone / F. Ahmad, I. N. Soelaiman, E. S. Mohd Ramli, T. N. Hooi, F. H. Suhaimi // Clinics. - 2011. - 66(5). - P. 849-853

9. Prevalence of canine obesity, obesity-related metabolic dysfunction, and relationship with owner obesity in an obesogenic region of Spain / J. A. Montoya-Alonso, I. Bautista-Castaño, C. Peña , L. Suárez et al. // Front. Vet. Sci. - 2017. - 4. - P. 59. doi: 10.3389/fvets.2017.00059

10. Kovaleva O. N. Metabolycheskyi syndrom: problemы dyahnostyky y prohnostycheskye kryteryy / O. N. Kovaleva, N. A. Kravchenko, T. N. Ambrosova, S. V. Vynohradova, Kharkovskyi hosudar. med. un-t «Vnutrenniaia medytsyna». - № 1(7). -2008. - S. 21-25.[in Russian]

11. Is the metabolic syndrome an intracellular Cushing state? Effects of multiple humoral factors on the transcriptional activity of the hepatic glucocorticoid-activating enzyme (11 $\beta$ hydroxysteroid dehydrogenase type 1) gene / Y. Iwasaki, S. Takayasu, M. Nishiyama, M. Tsugita, et al. // Mol. Cell. Endocrinol. - 2008. - 285. - P. 10-18.

12. Overexpression of $11 \beta$-hydroxysteroid dehydrogenase 1 in visceral adipose tissue and underexpression of endothelial nitric oxide synthase in the adrenal cortex of dogs with hyperadrenocorticism / D. D. Miceli, A. MB. Abiuso, P. N. Vidal, M. F. Gallelli et al. // Open Vet J. - 2018. - 8(1). P. 77-85. doi: 10.4314/ovj.v8i1.13. Epub 2018Mar 18.

Рецензент - С. М. Кулініч, д. вет. н., професор, Полтавська державна аграрна академія.

UDC 19.576 .858

doi: $10.36359 /$ scivp.2019-20-2.59

\title{
THE MAIN DIRECTIONS OF USE BIOLOGICAL MATERIAL TO PROVIDE THE EFFICIENCY OF LABORATORY SUPPLY IN AGRICULTURAL PRODUCTS TESTING IN UKRAINE
}

\author{
V. O. Ushkalov, O. Ju. Kepple
}

\author{
Ukrainian Laboratory of Quality and Safety of Products \\ of National University of Life and Environmental Sciences of Ukraine \\ 7, Mashynobudivnykiv str., Chabany, Kyiv region, 08162, Ukraine
}

Ukraine has significant resource potential for the agrarian sector development and improving the efficiency of agricultural production. An effective mechanism for controlling agro-industrial products is monitoring of indicators of quality and safety not only of finished products but also of all components involved in its manufacturing (soil and water as the main resource for agricultural production, plant protection products, mineral and organic fertilizers, seeds of agricultural cultures, etc. We analyzed normative documents on the accreditation of laboratories and international recommendations concerning the rational use of standardized biological material in the testing activity. We conducted the analysis of the testing activity results of the Ukrainian laboratory of quality and safety of agricultural products (ULQSAP). So, the expediency of optimizing the functioning of 
biological material collections in scientific institutions substantiated. The conducted analysis testifies to expediency of creation the national bioresource center, which will unite informationally all the functioning collections of biological material in order to increase the efficiency of its innovative potential.

Keywords: AGRICULTURAL PRODUCTS, BIOLOGICAL MATERIAL, COLLECTIONS, NORMATIVE DOCUMENTS.

Agricultural production in our country is one of the most important sectors of the economy, which ensures food security. Food security of citizens is one of the main components of economic security of the country [1]. Ukraine has significant resource potential for developing the agrarian sector and improving the efficiency of agricultural production. However, in the consumer market quite often there is an unfair business activity in the production and sale of counterfeit and / or counterfeit products. This applies both to food and raw materials for their manufacture, and to the protection of plants, fertilizers, seeds, etc. [2]. That is, the low level of competitiveness of domestic products of the agrarian sector in the world market indicates the need to ensure proper control of the quality and safety of not only finished products, but also all technological processes in its production.

An effective mechanism for controlling agro-industrial products is monitoring of indicators of quality and safety not only of finished products but also of all components involved in its production (soil and water as the main resource for agricultural production, plant protection products, mineral and organic fertilizers, seeds of agricultural cultures, etc. [3].

That is, at the time of demand, the role of proper/efficient laboratory support of production in the agrarian sector increases. Given the importance of production of export-oriented products, the role of accredited laboratories also increases. The presence of accreditation testifies to the official recognition of the ability of the laboratory to meet the requirements of customers in the field of testing, measurement or research. Accreditation takes into account: technical equipment and competence of the laboratory, that is, the minimum required level of equipment for testing and research in a certain field of activity, competence of staff (requirements for the composition, number and qualification of laboratory staff); the functioning of the quality system (rules and standards for the implementation of the basic processes of the laboratory), through which it is possible to guarantee stable work and obtaining reliable results of research, testing or inspections $[4,5]$.

The purpose of work is to determine the directions of infrastructure development for the laboratory support of the production of export-oriented agro-industrial products.

Materials and methods. The analysis of the results obtained in 2014-2017 in the Ukrainian Laboratory of Quality and Safety of Agricultural Product (ULQSAP) of the National University of Life and Environmental Sciences (accredited in accordance with the requirements of DSTU ISO / IEC 17025: 2006 (ISO / IEC 17025: 2005) for determination more than 370 indicators of quality and safety). Selection of samples (water, soil, grain, seeds, forage, fertilizers, pesticides, biological preparations, eggs, oils and fats, crop production, livestock, food products and food additives, etc.) for testing, conducting analytical studies and obtaining results are carried out accordingly, the documents regulating the order of work. Data analysis was carried out on the requirements for accreditation and technical competence of laboratories, as well as the use of standardized materials used in the conduct of research.

Research results and their discussion. The results of the analysis indicate that accreditation is required for those laboratories whose performance should be recognized by other market participants or the professional community [6]. These laboratories include test laboratories institutions that work with different types of products, materials and environments. Their purpose is to conduct tests of samples (products, materials or environmental elements) for compliance with the parameters set in the regulatory documents. Analytical laboratories - solving research tasks. Accreditation of analytical laboratories allows ensuring the reliability of the determination of the elemental composition of the samples under study. This is necessary to recognize the results of 
research by other participants in economic activity. The scope of accreditation of the laboratory may vary, depending on the purpose of its creation.

It must be taken into account that not every laboratory needs accreditation to perform the tasks. In certain cases, when there is no need to recognize the results of laboratories from other participants in the economic activity, the accreditation of the laboratory may not be carried out. In particular, at this time it is a training laboratory (at educational institutions) or a laboratory that solves highly specialized tasks (scientific laboratories).

The features of the ULQSAP of agrarian and industrial complex activities are that it is simultaneously a research and testing laboratory of the university accredited in accordance with the requirements of DSTU ISO / IEC 17025: 2006 and confirms its competence by participating in the laboratory comparisons of results organized by domestic and international coordinators. That is, a certain range of researches carried out in the laboratory does not require compulsory accreditation, namely - scientific research projects (in the ULQSAP of the agrarian and industrial complex, in the average year, 3-5 scientific research projects by state order, 6-15 scientific research projects under economic contracts and 2- 3 initiative scientific themes).

At the same time, it should be noted that both the testing activity and the execution of scientific research require the availability of standards. With regard to standards for chromatographic (gas, liquid) and spectral (emission, absorption and mass spectrometric) studies, the necessary analytical standards are developed and provided by companies such as Sigma-Aldrich, Romer Labs, etc. In particular, the analytical standards of mycotoxins, pesticides, heavy metals, alcohols, etc. are used in the ULQSAP. The market for biological standards is also rich in offers (National Institute of Biological Standards and Control (NIBSC), LGC Ltd, OIE reference laboratory, and others). For example, in Ukraine - in the State Research and Control Institute of Biotechnology and strains of microorganisms - it is developed, manufactured and delivered to interested microorganism test culture organizations (https://drive.google.com/file/d/0B-9dlmwAZcW7WkhGSm1JTTVIMkE/view) Standard test strains of microorganisms are used in accredited laboratories to confirm the ability of nutrient media and differential diagnostic tests to ensure the growth of bacteria and / or fungi in the research, manufacture of biologics and control of their quality, and so on.

The availability of standard biological material is a prerequisite for the survival of cellular biotechnology, genetic engineering, microbiology - that is, biotechnology in the broadest sense of the word. In accordance with modern scientific concepts, the term "biological material" means any material containing genetic information and is capable of self-reproduction or reproduction in the biological system [7].

Nowadays a number of international organizations are trying to promote economic growth and disseminate the positive experience of socio-economic policy. For example, the Organization for Economic Co-operation and Development (OECD) is an international organization that brings together 35 economically developed countries of the world - (USA, Germany, France, Australia, Canada, Switzerland, Norway, South Korea, Japan and others). In order to meet the current requirements for the further development of life sciences and biotechnologies, in particular to increase the efficiency of analytical research, the OECD in 2001 proposed a new concept for storage and supply of high quality biological materials and information about them, namely the creation of biological resource centers (BRCs) [8 ] BRCs should provide the scientific infrastructure with the relevant standard bio-resources in order to better realize the benefits of biotechnology. As a result of consultations in 2007, recommendations for the quality management system of BRC collections were developed. The OECD Biosafety Good Practice Handbook (2007) for BRCs describes methods and protocols for safe handling and handling of biological materials. BRCs should ensure the proper storage, maintenance and exchange of biological resources [9, 10]. Microbial resource centers are institutions that can protect, maintain and distribute authenticated microbial strains, their genomic DNA and related materials. In addition to taxonomy, the use of deposited strains allows for scientific 
research at a higher methodological level, which leads to a significant improvement in the results [11].

Collections of microorganisms in Ukraine function and are used in scientific researches, the results of which are used in applied biotechnology, pharmacology, veterinary medicine, agronomy, health care, ecology, etc. Thus, in the National Center for Microorganism Streams, the State Scientific-Control Institute for Biotechnology and the strains of microorganisms maintain active strains of microorganisms and cell cultures to meet the needs of veterinary medicine (used for the production and control of veterinary immunobiological drugs in Ukraine) [7].

However, the needs of the modern market of "biological standards" are not limited to the use of test strains of microorganisms. For example, in the testing activity of the ULQSAP, the use / planning of the use of laboratory cultures of algae (Desmodesmus subspicatus, Phaeodactylum tricornutum, Selenastrum gracile, Chlorella vulgaris, Spirulina (Arthrospira) platensis), Infusoria (Tetrahymena pyriformis, Colpoda steinii) Daphnia (Daphnia magna, Ceriodaphnia dubia), fish (Poecilia reticulate, Carassius), earthworms (Eisenia fetida), entomophages, in particular Trichogramma, Gabrobracon, Dibrachus, Ascogaster, Phytoseiidae, Cereal moths (Sitotroga cerealella), Ephestia kuehniella (Ephestia kuehniella), bees (Apis mellifera L), and radish sowing (Rap anus sativus L.). In addition, according to the results of testing, it is possible to create a collection of cultures-phytopathogens, micromycetes, soil microorganisms of certain ecological trophic groups (ammonifiers, amylolytic, pedotropic, oligotrophic, actinomycetes, etc.), DNA of genetically modified plants, etc.

That is, the modern interpretation of the concept of "biological resources" raises the task of expanding the biological resource base and the development of biotechnology, in accordance with the recommendations of the OECD. In other words, at the time the issue is to ensure the unified management of collections in relation to the storage and circulation of biological materials used in economic activities, in particular testing. Centers of biological resources should become an element of the scientific infrastructure for the implementation of scientific achievements in biotechnology.

It is important to emphasize the fact that bio-resources centers should be authorized not only to identify, collect, control quality, classification, registration, storage, reproduction, distribution of storage facilities, but also the merging of existing collections of different biomaterials into a single information network, training and training of relevant expert staff necessary to ensure the effective functioning of such centers. Biological collection is a systematic storage of a set of samples of biological material of any type. On this basis, it is possible to distinguish several types of biological collections depending on the types of biological material and storage methods stored in them [12]:

- cryopreservation, in which the material is stored in a frozen (and lyophilized) form, including nucleic acids;

- materials of zoological museums and herbaria, such collections can be used both for the study of biodiversity, as it is a valuable source of DNA;

- computer databases (collections of biological information) containing information on the primary, secondary and tertiary structure of biological molecules, such as GenBank (nucleotide sequences of genomes of different organisms, http: //www.ncbi.nlm.nih.gov/genbank/ ) and Protein Data Bank (tertiary protein structures, http://www.rcsb.org/ pdb / home / home.do).

The functional purpose of the collection of biomaterials may be:

- research, in cases where samples are stored in research laboratories and are necessary for their daily activities. Types of samples in such collections can be very different - from individual biological molecules to whole organisms;

- commercial, whose funds are for sale (sex cells, blood cells, etc.). For example, the Animal Blood Bank was created at the Faculty of Veterinary Medicine of NULES of Ukraine;

- government collections that are collected and maintained in the interests of the state. First of all, this category includes collections whose purpose is to preserve biodiversity (zoos, botanical gardens, etc.). In addition, these collections are designed to regulate the effective use of biological 
resources. In the US, the Natural Product Repository has been created in the National Institutes of Health, in Russia, the status of the national bioresource center is provided by the All-Russian Collection of Industrial Microorganisms. In other countries, work is under way to build and maintain the functioning of biological resource centers.

It should be noted that the functioning of biomaterial collections is considered at the OECD level as one of the key issues of national biosafety, since, for example, in the context of a "crisis", the absence of its own collection of producer cells for industrial biotechnology (veterinary, agricultural) can have a negative impact on livestock farming and crop production respectively. An example of a crisis situation can be the period of the collapse of the former USSR, and the crisis in veterinary biotechnology due to the lack of production strains and technologies for the production of animal protection means.

As to the current state of functioning of collections of microorganisms in Ukraine, the following should be noted. In accordance with the Resolution of the Cabinet of Ministers of Ukraine No. 705 of October 12, 1994 "On the state system for the depositing of strains of microorganisms" by the state, three depositaries (collections) have been designated by the state for the purpose of ensuring the legal protection of strains of microorganisms and creating conditions for their timely wide use for biotechnological productions and scientific purposes:

- for the storage of non-pathogenic microorganisms the Institute of Microbiology and Virology of the National Academy of Sciences;

- Kiev Research Institute of Epidemiology and Infectious Diseases of the Ministry of Health of Ukraine has been designated for the storage of microorganisms pathogenic to humans;

- for the storage of microorganisms pathogenic to animals, the Kyiv branch of the State Scientific-Research Control Institute for Veterinary Medicines and Feed Additives (now the State Scientific Control Institute for Biotechnology and Microorganism Streams) has been identified.

Accordingly, research collections of microorganisms / other biomaterials were maintained in accordance with research institutes and faculties of educational institutions of biological, medical, veterinary and agricultural profile. Despite the invariable significant research and innovation potential of collections, its use requires additional impetus. One of the factors hindering their development is the isolation of existing collections, the ignorance of the scientific community about the availability and characteristics of the samples that are stored in them. World experience shows that this problem can be solved by creating a single information system that would provide communication between collections and potential users. To this end, it is necessary to keep records in existing collections and to create a single electronic database of storage facilities, standardization of requirements for their storage and ways to ensure their availability.

The main deterrent to the functioning of collections is the lack of targeted funding. At this time in Ukraine it is virtually impossible to find a source of material support for the proper maintenance of collections. However, attempts at financial and regulatory provision of collections for veterinary bio-industry in previous years were. For example, in 2006-2009 financial support of research collections of strains for veterinary biotechnology in the NSC IEKVM, IVM, IE, IP, ISGM NAAN and some higher educational institutions provided the State Committee for Veterinary Medicine through the State Scientific Control Institute of Biotechnology and strains of microorganisms, through the ordering of targeted research work on the study of biological properties in microorganisms that have been kept for a long time, the selection and identification of new topical strains of pathogens of animal diseases, etc.

Another problem that is critical for the development of collections is regulatory regulation of the circulation of biological resources, especially cross-border. The conducted analysis shows the expediency of creating a nationwide bio-resource center, which will unite (first of all information) all functioning collections of biological material in order to increase the efficiency of their innovative potential. To do this you need to:

- Revision of the status of bio-resources collections that function at this time; 
- creation of a single database containing information on all collections of biomaterials (formation of information and analytical system);

- development of effective measures to regulate the activities of collections and related fields of science and technology

- formation of a state program of scientific research in biomaterial collections;

- integration of national bio-resources centers into the global bio-resource information space.

\title{
CONCLUSIONS
}

An important direction in improving the efficiency of laboratory support for production activities in the agrarian sector of the economy is the organization of the proper functioning of biological resource centers. The scope of accreditation of the ULQSAP involves the use of a range of standardized biological material. That is, the actual task is to create a unit to support a collection of biological materials used in experimental and scientific activities.

\section{ОСНОВНІ НАПРЯМИ ВИКОРИСТАННЯ БІОЛОГІЧНОГО МАТЕРІАЛУ ДЛЯ ЗАБЕЗПЕЧЕННЯ ЕФЕКТИВНОСТІ ЛАБОРАТОРНОГО ПОСТАЧАННЯ ДЛЯ ДОСЛІДЖЕНЬ СІЛЬСЬКОГОСПОДАРСЬКОЇ ПРОДУКЦЇ̈ В УКРАЇНІ}

\author{
В. О. Уикалов, д-р вет. наук, професор, \\ О. Ю. Кеппл, канд. вет. наук
}

Українська лабораторія якості і безпеки продукції АПК НУБіП України вул. Машинобудівників, 7, с.м.т. Чабани, Києво-Святошинський р-н, Київська обл., 08162, Україна

\section{А Н О Т А Ц І Я}

Україна має значний ресурсний потенціал для розвитку аграрного сектору та підвищення ефективності сільськогосподарського виробництва. Ефективним механізмом контролю агропромислової продукції є моніторинг показників якості та безпеки не тільки готової продукції, але й усіх іiі компонентів (грунт та вода як основний ресурс для сільськогосподарського виробництва, засоби захисту рослин, мінеральні та органічні продукти). Проаналізовано нормативні документи щодо акредитації лабораторій та міжнародні рекомендації щодо раціонального використання стандартизованого біологічного матеріалу у випробувальній діяльності.

Проведений аналіз результатів дослідницької діяльності Української лабораторії якості i безпеки продукції АПК. Таким чином, обгрунтована доцільність оптимізації функціонування колекцій біологічного матеріалу в наукових установах. Проведений аналіз свідчить про доцільність створення національного біоресурсного центру, який інформаційно об'єднає всі діючі колекції біологічного матеріалу. з метою підвищення ефективності його інноваційного потенціалу.

Ключові слова: СІЛЬСЬКОГОСПОДАРСЬКА ПРОДУКЦІЯ, БІОЛОГІЧНИЙ МАТЕРІАЛ, КОЛЕКЦІЇ, НОРМАТИВНІ ДОКУМЕНТИ. 


\title{
ПУТИ РАЗВИТИЯ ИНФРАСТРУКТУРЫ ЛАБОРАТОРНОГО СОПРОВОЖДЕНИЯ ПРОИЗВОДСТВА ПРОДУКЦИИ АПК
}

\author{
В. А. Ушкалов, О. Ю. Кеппл
}

\begin{abstract}
Украинская лаборатория качества и безопасности продукции АПК НУБіП Украины ул. Машиностроителей, 7, с.м.т. Чабаны, Киево-Святошинский р-н, Киевская обл., 08162 , Украина
\end{abstract}

\section{А Н Н О Т А ЦИ Я}

Украина имеет значительный ресурсный потенциал для развития аграрного сектора и повышения эффективности сельскохозяйственного производства. Эффективным механизмом контроля агропромышленной продукции является мониторинг показателей качества и безопасности не только готовой продукции, но и всех ее компонентов (грунт и вода как основные ресурсы для сельскохозяйственного производства, средства защиты растений, минеральные и органические продукты). Проанализированы нормативные документы по аккредитации лабораторий и международные рекомендации по рациональному использованию стандартизированного биологического материала в испытательной деятельности. Проведен анализ результатов исследовательской деятельности Украинской лаборатории качества и безопасности продукции АПК. Таким образом, обоснована целесообразность оптимизации функционирования коллекций биологического материала в научных учреждениях. Проведенный анализ свидетельствует о целесообразности создания национального биоресурсного центра, который информационно объединит все действующие коллекции биологического материала. с целью повышения эффективности его инновационного потенциала.

Ключевые слова: ПРОДУКЦИЯ АПК, БИОЛОГИЧЕСКИЙ МАТЕРИАЛ, КОЛЛЕКЦИИ, НОРМАТИВНЫЕ ДОКУМЕНТЫ.

\section{References}

1. Ushkalov V.O. Monitorynh bioresursiv ta produktsii ahpromyslovoho kompleksuna pokaznyky yakosti i bezpeky yak skladova kontseptsii VOOZ-MEB «Hlobalne zdorovia / V.O. Ushkalov, V.V. Danchuk, Yu.S.Baranov, ta in. // Veterynarna medytsyna. Mizhvid. temat. nauk. zb.. - Kharkiv, 2016. - Vyp. 102. - S.219-223 (in Ukrainian).

2. Ushkalov V.O. Ekspertni doslidzhennia v ULIaBP APK / V.O. Ushkalov, O.P. Samkova, V.V. Danchuk, ta in. // Ahrarnyi visnyk Prychornomoria. Zbirnyk naukovykh prats. Veterynarni nauky. - 2017. - Vyp. 83. - S. 275-279 (in Ukrainian)

3. Food and Feed Taking stock of EU PUBLIC HEALTH, FOOD SAFETY, NIMAL and PLANT HEALTH POLICY achievements 2010-2014 [Elektronnyi resurs]/http://ec.europa.eu/health/docs/2010_2014_policy_achievements_en.pdf,

4. Rehlament (IeS) N 765/2008 Yevropeiskoho Parlamentu ta Rady, shcho vstanovliuie vymohy dlia akredytatsii ta nahliadu za rynkom shchodo realizatsii produktsii ta skasovuie Rehlament (IeES) N 339/93 [Elektronnyi resurs]http://zakon5.rada.gov.ua/laws/show/994_938, (in Ukrainian)

5. Zakon Ukrainy Pro akredytatsiiu orhaniv z otsinky vidpovidnosti [Elektronnyi resurs] http://zakon3.rada.gov.ua/laws/show/2407-14, (in Ukrainian)

6. Instruktsiia «Formuvannia sfery akredytatsii vyprobuvalnoi laboratorii» [Elektronnyi resurs] https://naau.org.ua/instruktsiya-formuvannya-sfery-akredytatsiyi-vyprobuvalnoyilaboratoriyi (in Ukrainian) 
7. Natsionalnyi tsentr shtamiv mikroorhanizmiv: stan i perspektyvy rozvytku / A.M. Holovko, V.O. Ushkalov, L.I. Akymenko, L.M. Davydovska// Veterynarna medytsyna Ukrainy, № 2, 2007, s. 35-36, (in Ukrainian)

8. Biological Resource Centres. Underpinning the future of life sciences and biotechnology /ORGANISATION FOR ECONOMIC CO-OPERATION AND DEVELOPMEN, 2001. - 68 r. [Elektronnyi resurs] http://www.oecd.org/science/biotech/2487422.pdf,

9. OECD Best Practice Guidelines for Biological Resource Centres, 2007. - 115 r. [Elektronnyi resurs] http://www.oecd.org/science/biotech/biologicalresourcecentres.htm,

10. OECD GLOBAL FORUM ON KNOWLEDGE ECONOMY: BIOTECHNOLOGY. GUIDANCE FOR THE OPERATION OF BIOLOGICAL RESEARCH CENTRES (BRCs) CERTIFICATION AND QUALITY CRITERIA FOR BRCs.- 2004.- [Elektronnyi resurs] http://www.oecd.org/science/biotech/23547743.pdf

11. Jörg Overmann. Significance and future role of microbial resource centers, Systematic and Applied Microbiology, Volume 38, Issue 4, June 2015, Pages 258-265.

12. Kamenskyi P. A. Byolohycheskye kollektsyy: stremlenye k ydealu/ P. A. Kamenskyi, A. Э. Sazonov, A. A. Fedianyn, V. A. Sadovnychyi / ACTA NATURAE | TOM 8 № 2 (29) 2016. [Elektronnyi resurs]https://cyberleninka.ru/article/n/biologicheskie-kollektsii-stremlenie-k-idealu(in Russian).

\section{Л I T Е P A T У P A}

1. Моніторинг біоресурсів та продукції агпромислового комплексу на показники якості і безпеки як складова концепції ВООЗ-МЕБ «Глобальне здоров’я / В.О. Ушкалов, В.В. Данчук, Ю.С. Баранов, та ін. // Ветеринарна медицина. Міжвід. темат. наук. зб.. - Харків, 2016. - Вип. 102. - C.219-223

2. Експертні дослідження в УЛЯБП АПК / В.О. Ушкалов, О.П. Самкова, В.В. Данчук, та ін. // Аграрний вісник Причорномор'я. Збірник наукових праць. Ветеринарні науки. - 2017. - Вип. 83. - С. 275-279

3. Food and Feed Taking stock of EU PUBLIC HEALTH, FOOD SAFETY, NIMAL and PLANT HEALTH POLICY achievements 2010-2014 [Електронний pecypc]/http://ec.europa.eu/health/docs/2010_2014_policy_achievements_en.pdf,

4. Регламент (СС) N 765/2008 Свропейського Парламенту та Ради, що встановлює вимоги для акредитації та нагляду за ринком щодо реалізації продукції та скасовує Регламент (СEC) N 339/93 [Електронний ресурс]http://zakon5.rada.gov.ua/laws/show/994_938,

5. ЗАКОН УКРАЇНИ Про акредитацію органів $з$ оцінки відповідності [Електронний pecypc] http://zakon3.rada.gov.ua/laws/show/2407-14,

6. Інструкція «Формування сфери акредитації випробувальної лабораторії» [Електронний pecypc] https://naau.org.ua/instruktsiya-formuvannya-sfery-akredytatsiyivyprobuvalnoyi-laboratoriyi/,

7. Головко А.М. Національний центр штамів мікроорганізмів: стан і перспективи розвитку / А.М. Головко, В.О. Ушкалов, Л.І. Акименко, Л.М. Давидовська// Ветеринарна медицина України, № 2, 2007, с. 35-36,

8. Biological Resource Centres. Underpinning the future of life sciences and biotechnology /ORGANISATION FOR ECONOMIC CO-OPERATION AND DEVELOPMEN, 2001. - 68 p. [Електронний pecypc] http://www.oecd.org/science/biotech/2487422.pdf,

9. OECD Best Practice Guidelines for Biological Resource Centres, 2007. - 115 p. [Електронний ресурс] http://www.oecd.org/science/biotech/biologicalresourcecentres.htm,

10. OECD GLOBAL FORUM ON KNOWLEDGE ECONOMY: BIOTECHNOLOGY. GUIDANCE FOR THE OPERATION OF BIOLOGICAL RESEARCH CENTRES (BRCs) 
CERTIFICATION AND QUALITY CRITERIA FOR BRCs.- 2004.- [Електронний ресурс] http://www.oecd.org/science/biotech/23547743.pdf,

11. Jörg Overmann. Significance and future role of microbial resource centers, Systematic and Applied Microbiology, Volume 38, Issue 4, June 2015, Pages 258-265,

12. Каменский П. А. Биологические коллекции: стремление к идеалу/ П. А. Каменский, А. Э. Сазонов, А. А. Федянин, В. А. Садовничий/ ACTA NATURAE, | TOM 8 № 2 (29) 2016. [Електронний pecypc]https://cyberleninka.ru/article/n/biologicheskie-kollektsiistremlenie-k-idealu/

Рецензент - О. В. Волосянко, д. вет. н., професор, Українська лабораторія якості і безпеки продукції АПК НУБіП України 